\title{
Homeopathy improves production and hatching probability of zebrafish eggs
}

\author{
Vanessa Lewandowski ${ }^{1}$, Cesar Sary ${ }^{2}$, Eric C. Campos ${ }^{2}$, Carlos A.L. de Oliveira ${ }^{2}$ \\ Ricardo P. Ribeiro ${ }^{2} \&$ Lauro D. Vargas ${ }^{2}$ \\ ${ }^{1}$ Faculty of Agrarian Science, Federal University of Grande Dourados, Dourados, Brazil \\ ${ }^{2}$ Department of Animal Science, State University of Maringá, Maringá, Brazil \\ Corresponding author: Vanessa Lewandowski (vanessalewandowski@ufgd.edu.br)
}

\begin{abstract}
The homeopathy has been practiced for many years, mainly using rodent as a research model. Zebrafish have been used as an animal model in different scientific areas and may represent an important model in studies with this therapy. This paper aimed to evaluate the action of Homeopatila $100^{\circledR}$ on the growth, the action on the liver and reproduction of zebrafish. The study was carried out with 192 six months old animals. The experimental period was three months, being evaluated the growth, the hepatosomatic and viscerosomatic indexes, the number of hepatocytes per area and the percentage of glycogen in these cells, performing the hepatic histology of males and females. It was evaluated the reproduction of the animals, checking the production and probability of hatching of the eggs. It was found that homeopathy increases the number of hepatocytes and glycogen in females, as well as improved the reproductive indices evaluated.
\end{abstract}

Keywords: Danio rerio; zebrafish; glycogen; hepatocytes; liver; reproduction

\section{INTRODUCTION}

Homeopathy, based on the principle of the "Law of Similars" and the use of drugs that retain biological activity, after dilutions and succussions (Ernst, 2002), when applied collectively is considered as population homeopathy. This form of administration considers a group of individuals kept under the same environmental conditions as a single organism and is widely used in the treatment of production animals (Benez et al., 2004). Homeopathic products have some advantages compared to other therapeutic forms, for example, they are easy to administer, do not leave residues in the body and do not contaminate the environment, which is characterized as important factors in food production (Benez et al., 2004).

The effect of homeopathy on productive performance and meat quality in fish has been evaluated, mainly for Nile tilapia. Remarkable results have been observed, such as increased muscle hypertrophy, survival, decrease in lipid content and omega 6:3 ratio (Júnior et al., 2012; Andretto et al., 2014). Scientific studies report that homeopathy causes minor liver damage, greater storage of glycogen and a lower hepatosomatic rate, besides not influencing the quality of meat and derived products and improving breeding rates, such as spawning frequency and larvae hatching (Valentim-Zabott et al., 2008; Siena et al., 2010; Braccini et al., 2013; Andretto et al., 2015; Fuzinatto et al., 2015; Lima et al., 2015; Pinheiro et al., 2015) demonstrating that the product Homeopatila $100^{\circledR}$, when acting as a hepatoprotective, can influence important factors in the production, growth, reproduction, and quality of meat.

In addition to the production of animals, homeopathy is studied in experimental models such as rats, mice and non-human primates (Bonamin et al., 2015; Chatfield et al., 2016). In this group, rats and mice correspond to $72 \%$ of the research of this therapy in the last 10 years, with the main purpose of using them as models of disease (Chatfield et al., 2016). In addition to rats and mice, the Danio rerio fish popularly known as zebrafish has stood out as an animal model.

The use of zebrafish is due to its genetic characteristics, which have a fully sequenced genome, where it is found that $71 \%$ human genes have at least one orthologous gene in zebrafish (Vilella et al., 2008). Moreover, $81 \%$ of the human genes related to the cause of diseases are orthologs of the genes of this fish (Howe et al., 2013). Besides the genetic factors, some characte-

Corresponding editor: Jesús Ponce Palafox 
characteristics favor its use as an animal model in the laboratory, such as small size, robustness, short life cycle, generation of large numbers of offspring and mainly ease and low cost to keep it in research environments (Nasiadka \& Clark, 2012). Zebrafish can also be used in model studies in comparison to other animals, especially other fish species, besides being considered a standard organism concerning humans. The use of zebrafish as an animal model and a research tool in several areas in studies related to homeopathy is emphasized.

The evaluation of the effect of the homeopathic complex Homeopatila $100^{\circledR}$ can elucidate the results already obtained in Nile tilapia, as well as to provide more information that allows its use in other aquatic organisms. This study aimed to evaluate the effect of the homeopathic complex Homeopatila $100^{\circledR}$ on the productive performance, reproduction and evaluation of the liver of zebrafish.

\section{MATERIALS AND METHODS}

\section{Ethics committee}

The manipulations and experiments with the animals were carried out following the regulations established by the Ethics Committee of the State University of Maringá (SUM), with the approval of the project with protocol number: 4045281116.

\section{Animals and experimental period}

The study was developed at the Zebrafish Laboratory of SUM, from January to April 2017, totaling 90 days. Six-month-old zebrafish with $0.30 \pm 0.08 \mathrm{~g}$ in weight and $28.30 \pm 2.06 \mathrm{~mm}$ in total length were kept in $30 \mathrm{~L}$ aquaria, with constant aeration and 14:10 h light-dark cycle, as recommended for the species.

\section{Design and experimental diets}

The study was carried out in a completely randomized design, with four treatments and four replications. A total of 192 fish were used, distributed in 16 aquaria, totaling 12 animals per experimental unit. Fish were fed four times a day $(08: 00,11: 00,14: 00$ and 17:00 h) to apparent satiety, with Bern Aqua commercial diet, containing $57 \% \mathrm{CP}$ and $300-500 \mu \mathrm{m}$ particle size, with the inclusion of the homeopathic complex Homeopatila $100^{\circledR}$ (RealH). The treatments consisted of inclusion levels of the homeopathic complex, being a control treatment $\left(20 \mathrm{~mL} 30^{\circ} \mathrm{gl} \mathrm{Hydroalcoholic} \mathrm{solution}\right)$ and three treatments with the inclusion of 20,40 and $60 \mathrm{~mL}$ $\mathrm{kg}^{-1}$ of Homeopatila $100^{\circledR}$ in the feed (Table 1).

\section{Experimental methodology}

During the experimental period, initial and final biometry was performed, and the length $(\mathrm{mm})$ and weight $(\mathrm{g})$ of
Table 1. The composition of the homeopathic nucleus Homeopatila $100^{\circledR}$. REALH (www.realh.com.br).

\begin{tabular}{ll}
\hline Compound & $1000 \mathrm{~g}^{-1}$ \\
\hline Iodum & $10^{-24}$ \\
Sulfur & $10^{-60}$ \\
Natrum muriaticum & $10^{-400}$ \\
Streptococcinum & $10^{-60}$ \\
Vehicle $\left(30^{\circ}\right.$ gl ethyl alcohol) & Q.s.p. \\
\hline
\end{tabular}

all the animals used in the study were measured. Fish were fasted for $24 \mathrm{~h}$ and then anesthetized with a solution containing water and $100 \mathrm{ppm}$ clove oil (Eugenol) as described by Grush et al. (2004), weighed and measured.

Ninety days after the onset of the experiment, the final biometry was performed to evaluate the productive performance. Six fish from each experimental unit (three males and three females) were euthanized by immersion in ice, destined for histological assessment of the liver and obtaining the hepatosomatic and gonadosomatic indices. Three couples per experimental unit were assigned to reproduction and evaluation of reproductive parameters.

\section{Productive performance}

With the final biometric data, animal performance was obtained according to the sexes of the parameters total weight $(\mathrm{g})$; total length $(\mathrm{mm})$; liver weight $(\mathrm{g})$; and gonad weight $(\mathrm{g})$. In addition, the hepatosomatic index $(\mathrm{HI})=($ liver weight $/$ fish weight $) \times 100$; and gonadosomatic index $(\mathrm{GI})=(\operatorname{gonad}$ weight $/$ fish weight $) \times 100$ were calculated.

\section{Histology}

Histological evaluation was conducted in the liver of four animals per experimental unit, two males and two females. The samples were collected, washed with a physiological solution $(0.9 \% \mathrm{NaCl})$ fixed in Bouin for $6 \mathrm{~h}$ and later stored in $70 \%$ alcohol. The material was dehydrated in an ascending series of alcohol, diaphanized in xylol and embedded in paraffin to obtain the histological sections in the Laboratory of animal histology, Department of Morphology, State University of Maringá.

For hepatocyte count per area, the slides were stained with Hematoxylin and Eosin, while for verification of intracellular glycogen (\%), we used the staining with periodic acid Schiff (PAS) + hematoxylin. The slides were photographed under Olympus optical microscope at 40x magnification for hepatocyte counts and 100x for glycogen verification. Subsequent analyses were performed using Image Pro Plus software. 


\section{Breeding and reproductive parameters}

At the end of 90 experimental days, three couples of each replicate were selected for mating. They were removed from the aquarium and housed in $1.5 \mathrm{~L}$ reproduction structures, composed of an external structure and an internal structure with a screen bottom so that after spawning, the eggs remained at the bottom of the external structure, protected from predation.

In the case of spawning, eggs were collected, sanitized with water and kept in Petri dishes, in the amount of 50 eggs per dish. The number of eggs per female and the hatching probability $(\%)=$ (number of hatched larvae/total number of eggs $) \times 100$ were analyzed.

\section{Water quality}

The water temperature was verified daily, in the morning (08:00) and the afternoon (17:00), with the aid of a digital thermometer, remaining with an average of $27.2 \pm 1.4^{\circ} \mathrm{C}$ during the experimental period. Values of $\mathrm{pH}$ and dissolved oxygen (DO) were measured weekly using a YSI multiparameter probe, maintaining the values of $7.3 \pm 0.8$ and $6.5 \pm 0.6 \mathrm{mg} \mathrm{L}^{-1}$ for $\mathrm{pH}$ and $\mathrm{DO}$, respectively.

\section{Statistics}

The data obtained were subjected to Bayesian analysis. For this, the means were tested for normal distribution with homogeneous variance $\left(Y \mid \mu, \sigma^{2} \sim \operatorname{Normal}\left(\mu, \sigma^{2}\right)\right.$, $\mu$ real, $\sigma^{2}=\sigma^{2}$ e $>0$ ); normal distribution with heterogeneous variance $\left(Y \mid \mu, \sigma^{2} \sim \operatorname{Normal}\left(\mu, \sigma^{2}\right), \mu\right.$ real, $\left.\sigma^{2} \neq \sigma^{2} \mathrm{e}>0\right)$ and gamma distribution $(Y \mid \alpha, \beta \sim \operatorname{Gama}(\alpha, \beta), \alpha$ e $\beta>0$, whose mean is $\alpha / \beta)$. The most parsimonious distribution was defined following the Deviance Information Criterion (DIC) (Spiegelhalter et al., 2002). Due to the characteristics of the parameters, survival and hatching followed binomial distribution $(Y \mid \theta \sim \operatorname{Binomial}(\mathrm{n}, \theta)$, that is, the observed value in mortality and non-hatched larvae, with probability of survival and hatching; number of eggs and hatched larvae, Poisson-gamma distribution ( $\lambda \mid Y \sim \operatorname{Gama}(\alpha+\mathrm{t}, \beta+\mathrm{n})$, whose $(\lambda)$ is the mean number of eggs and hatched larvae.

Non-informative a priori distributions were considered for all parameters under study. Obtaining the marginal distributions a posteriori for the parameters were obtained using the BRugs package of $\mathrm{R}$ ( $\mathrm{R}$ Development Core Team, 2018) 1,000,000 values were generated in an MCMC (Monte Carlo Markov Chain) process, considering a sampling period of 100,000 initial values and withdrawal interval of 10 . The convergence of the chains was verified by the criteria of Heildelberger \& Welch (1983) and Geweke (1992) and, implemented in the coda package of $\mathrm{R}$. The significance of the treatments was checked by the presence or not of zero in the respective $95 \%$ credible interval $(\operatorname{ICr}(\Delta, 95 \%)$ for the contrasts.

\section{RESULTS}

Differences were detected in the productive parameters of total weight and hepatosomatic index for males and females, respectively (Table 2). The highest final weight for males was verified for the control treatment, without the inclusion of the homeopathic complex and with $20 \mathrm{~mL}$ inclusion per $\mathrm{kg}$ feed, while the animals subjected to treatments with 40 and $60 \mathrm{~mL}$ of the product had lower weight, differing only with control. About the hepatosomatic index, the females fed a diet containing $20 \mathrm{~mL}$ Homeopatila $100^{\circledR}$ presented lower value when compared to the females of the control treatment.

Higher values were observed for the females in all parameters evaluated, mainly for the hepatosomatic and gonadosomatic indices. The treatments did not influence the survival of the animals, which was above $90 \%$ in all levels of Homeopatila $100^{\circledR}$ evaluated $(0 \mathrm{~mL}$ $\mathrm{kg}^{-1}: 93.99 \%, 20 \mathrm{~mL} \mathrm{~kg}^{-1}: 90.02 \%, 40 \mathrm{~mL} \mathrm{~kg}^{-1}: 94.00 \%$, and $60 \mathrm{~mL} \mathrm{~kg}^{-1}: 91.99 \%$ ).

There was a difference in the number of hepatocytes and the percentage of glycogen (Table 3). The hepatocyte count varied with the treatments considering both sexes, a lower number was observed for the control treatment. For the females, it was observed that the animals fed diets containing 20 and $40 \mathrm{~mL}$ of the homeopathic complex per $\mathrm{kg}$ of diet had a higher number of hepatocytes; glycogen occupied from 31.47 to $49.31 \%$ of the total hepatocyte area, being lower in the control treatment. In females fed a diet containing $40 \mathrm{~mL}$ of the product per $\mathrm{kg}$ of diet, it occupied $49.31 \%$ of the total area of the hepatocytes, differing from the other treatments. The reproductive parameters also differed, with higher values for the treatments with 40 and $60 \mathrm{~mL} \mathrm{~kg}^{-1}$ for the number of eggs, being 416 and 402, respectively (Fig. 1).

There was a higher hatching probability, with a higher number of larvae for the treatment with $60 \mathrm{~mL}$ of Homeopatila $100^{\circledR}$ per $\mathrm{kg}$ of feed and a lower value for the control treatment (Fig. 2).

\section{DISCUSSION}

There were higher values of the productive parameters for the females compared to the males. At the end of the experimental period, the animals used were nine months old and were able to reproduce, since zebrafish 
Table 2. Productivity parameters of zebrafish Danio rerio fed different levels of Homeopatila $100^{\circledR}$ (Mean, followed by the range in parentheses and standard deviation (SD)). Different superscript letters in the same column indicate differences between treatments.

\begin{tabular}{|c|c|c|c|c|c|}
\hline \multirow{2}{*}{ Variables } & \multirow{2}{*}{$\begin{array}{l}\text { Treatments } \\
\left(\mathrm{mL} \mathrm{kg}^{-1}\right)\end{array}$} & \multicolumn{2}{|l|}{ Males } & \multicolumn{2}{|l|}{ Females } \\
\hline & & A posteriori means & SD & A posteriori means & SD \\
\hline \multirow{4}{*}{$\begin{array}{l}\text { Total weight } \\
\text { (g) }\end{array}$} & 0 & $0.76^{\mathrm{a}}(0.71-0.83)$ & \pm 0.072 & $1.09^{\mathrm{a}}(0.95-1.23)$ & \pm 0.07 \\
\hline & 20 & $0.74^{\mathrm{ab}}(0.68-0.80)$ & \pm 0.052 & $1.16^{\mathrm{a}}(1.02-1.29)$ & \pm 0.07 \\
\hline & 40 & $0.67^{\mathrm{b}}(0.6182-0.7371)$ & \pm 0.033 & $1.11^{\mathrm{a}}(0.98-1.25)$ & \pm 0.07 \\
\hline & 60 & $0.67^{\mathrm{b}}(0.61-0.73)$ & \pm 0.033 & $1.02^{\mathrm{a}}(0.88-1.15)$ & \pm 0.07 \\
\hline \multirow{4}{*}{$\begin{array}{l}\text { Total lenght } \\
(\mathrm{mm})\end{array}$} & 0 & $40.88^{\mathrm{a}}(39.13-42.64)$ & \pm 0.884 & $43.92^{\mathrm{a}}(42.28-45.58)$ & \pm 0.83 \\
\hline & 20 & $39.51^{\mathrm{a}}(37.76-41.28)$ & \pm 0.887 & $43.83^{\mathrm{a}}(42.18-45.50)$ & \pm 0.83 \\
\hline & 40 & $40.52^{\mathrm{a}}(38.77-42.29)$ & \pm 0.886 & $44.05^{\mathrm{a}}(42.40-45.71)$ & \pm 0.83 \\
\hline & 60 & $40.11^{\mathrm{a}}(38.36-41.85)$ & \pm 0.881 & $43.74^{\mathrm{a}}(42.10-45.38)$ & \pm 0.83 \\
\hline \multirow{4}{*}{$\begin{array}{l}\text { Liver weight } \\
\text { (g) }\end{array}$} & 0 & $0.008^{\mathrm{a}}(0.005-0.012)$ & \pm 0.001891 & $0.042^{\mathrm{a}}(0.030-0.059)$ & \pm 0.009 \\
\hline & 20 & $0.008^{\mathrm{a}}(0.006-0.012)$ & \pm 0.001614 & $0.032^{\mathrm{a}}(0.026-0.040)$ & \pm 0.004 \\
\hline & 40 & $0.006^{\mathrm{a}}(0.003-0.010)$ & \pm 0.001710 & $0.033^{\mathrm{a}}(0.026-0.042)$ & \pm 0.009 \\
\hline & 60 & $0.008^{\mathrm{a}}(0.005-0.014)$ & \pm 0.002337 & $0.035^{\mathrm{a}}(0.028-0.045)$ & \pm 0.005 \\
\hline \multirow{4}{*}{$\begin{array}{l}\text { Gonad weight } \\
(\mathrm{g})\end{array}$} & 0 & $0.008^{\mathrm{a}}(0.006-0.012)$ & \pm 0.001925 & $0.107^{\mathrm{a}}(0.077-0.150)$ & \pm 0.025 \\
\hline & 20 & $0.010^{\mathrm{a}}(0.007-0.014)$ & \pm 0.001623 & $0.194^{\mathrm{a}}(0.111-0.343)$ & \pm 0.107 \\
\hline & 40 & $0.006^{\mathrm{a}}(0.004-0.013)$ & \pm 0.002600 & $0.145^{\mathrm{a}}(0.121-0.173)$ & \pm 0.024 \\
\hline & 60 & $0.008^{\mathrm{a}}(0.006-0.009)$ & \pm 0.000892 & $0.140^{\mathrm{a}}(0.089-0.139)$ & \pm 0.066 \\
\hline \multirow{4}{*}{$\begin{array}{l}\text { Hepatosomatic } \\
\text { index }(\%)\end{array}$} & 0 & $1.05^{\mathrm{a}}(0.753-1.472)$ & \pm 0.1983 & $4.35^{\mathrm{a}}(3.40-5.58)$ & \pm 0.583 \\
\hline & 20 & $1.13^{\mathrm{a}}(0.762-1.699)$ & \pm 0.2654 & $2.770^{\mathrm{b}}(2.12-3.64)$ & \pm 0.411 \\
\hline & 40 & $1.02^{\mathrm{a}}(0.517-1.630)$ & \pm 0.3835 & $3.103^{\mathrm{ab}}(2.32-3.04)$ & \pm 1.489 \\
\hline & 60 & $1.26^{\mathrm{a}}(0.855-1.875)$ & \pm 0.2984 & $3.500^{\mathrm{ab}}(2.70-3.45)$ & \pm 0.526 \\
\hline \multirow{4}{*}{$\begin{array}{l}\text { Gonadosomatic } \\
\text { index }(\%)\end{array}$} & 0 & $1.070^{\mathrm{a}}(0.758-1.612)$ & \pm 0.3056 & $11.010^{\mathrm{a}}(8.95-13.67)$ & \pm 1.269 \\
\hline & 20 & $1.287^{\mathrm{a}}(0.881-2.027)$ & \pm 0.4008 & $15.030^{\mathrm{a}}(10.18-23.00)$ & \pm 4.835 \\
\hline & 40 & $1.040^{\mathrm{a}}(0.643-2.044)$ & \pm 0.9786 & $13.130^{\mathrm{a}}(11.61-14.88)$ & \pm 9.355 \\
\hline & 60 & $1.104^{\mathrm{A}}(0.881-1.421)$ & \pm 0.1382 & $12.780^{\mathrm{a}}(9.54-17.25)$ & \pm 2.574 \\
\hline
\end{tabular}

Table 3. Hepatic parameters of zebrafish Danio rerio fed different levels of Homeopatila $100^{\circledR}$ (mean, followed by the range in parentheses and standard deviation (SD)). Different superscript letters in the same column indicate differences between treatments.

\begin{tabular}{lccccc}
\hline \multirow{2}{*}{ Variables } & Treatments & \multicolumn{3}{c}{ Males } & \multicolumn{2}{c}{ Females } \\
\cline { 3 - 6 } & $(\mathrm{mL})$ & A posteriori means & SD & A posteriori means & SD \\
\hline \multirow{4}{*}{ Number of hepatocytes } & 0 & $251^{\mathrm{b}}(238-264)$ & \pm 6 & $302^{\mathrm{c}}(287-318)$ & \pm 8 \\
& 20 & $293^{\mathrm{a}}(279-307)$ & \pm 7 & $441^{\mathrm{b}}(425-458)$ & \pm 9 \\
& 40 & $286^{\mathrm{a}}(273-300)$ & \pm 7 & $432^{\mathrm{b}}(416-449)$ & \pm 8 \\
& 60 & $284^{\mathrm{a}}(270-297)$ & \pm 7 & $406^{\mathrm{a}}(388-423)$ & \pm 9 \\
\hline \multirow{4}{*}{ Glycogen $(\%)$} & 0 & $34.24^{\mathrm{a}}(31.71-36.97)$ & \pm 1.33 & $31.47^{\mathrm{c}}(29.50-33.56)$ & \pm 1.03 \\
& 20 & $33.38^{\mathrm{a}}(31.41-35.47)$ & \pm 1.03 & $35.77^{\mathrm{b}}(32.51-39.36)$ & \pm 1.74 \\
& 40 & $35.91^{\mathrm{a}}(33.80-38.13)$ & \pm 1.09 & $49.31^{\mathrm{a}}(47.46-51.25)$ & \pm 0.96 \\
& 60 & $35.75^{\mathrm{a}}(33.57-38.05)$ & \pm 1.14 & $36.62^{\mathrm{b}}(34.55-38.79)$ & \pm 1.08 \\
\hline
\end{tabular}

specimens may show sexual maturity within 90 days (Spence et al., 2007). Because they were kept under ideal conditions of environment and management, development was favored with increasing gonadal weight.

The ovary exerts influence on the body weight of females, due to the occupation of a large part of the celomatic cavity, demonstrated by the gonadosomatic index. The results found for the gonadosomatic index were within the values described for zebrafish by
Chang et al. (2013) and Gonzales \& Law (2013) in their control treatments, with values close to $1 \%$ for males and $13 \%$ for females.

The liver of zebrafish is composed of three lobes, two lateral and one ventral (Goessling \& Sadler, 2015). It is an important organ of the organism that exerts different functions, among them, those related to metabolic activities (synthesis of proteins, lipids, carbohydrates and vitellogenin) and in responses immunological. The liver is composed of hepatocytes, 


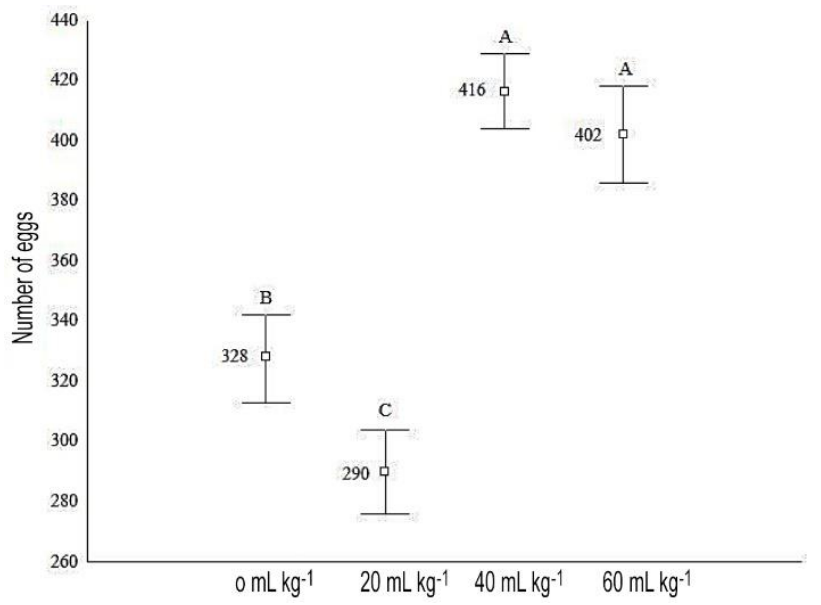

Figure 1. The mean number of eggs per zebrafish Danio rerio female fed different levels of Homeopatila $100^{\circledR}$. Different letters indicate statistically significant differences between treatments.

which are the primary functional cells and where reserve substances such as glycogen and lipids are accumulated.

The amount of these substances interferes with the liver weight and consequently in the hepatosomatic index. However, in the present study, there was no change in the weight of this organ about the treatments, for both males and females. There was variation in the index for females fed diets containing $20 \mathrm{~mL}$ Homeopatila $100^{\circledR}$ per kg of feed when compared to the control. This result may be due to their weight, which, although not statistically different, was higher than that observed for the other treatments.

This result contrasts with Pinheiro et al. (2015), who studied the same levels of Homeopatila $100^{\circledR}$ in tambaqui (Colossoma macropomum), and found a higher hepatosomatic index for this treatment when compared to the inclusion of $40 \mathrm{~mL}$ per $\mathrm{kg}$ of diet. The hepatosomatic index from 1.01 to $1.3 \%$ for males is similar to that described by Chang et al. (2013) for zebrafish, being $1.59 \%$ for individuals of the same sex. On the other hand, it is higher considering the females, which was $2.81 \%$ and in the present study, the values observed ranged from 2.70 to $4.34 \%$.

There was variation regarding the number of hepatocytes, with higher values in the animals treated with the homeopathic complex Homeopatila $100^{\circledR}$ in comparison to the control. For females, a higher number of these cells were verified, mainly with diets containing 20 and $40 \mathrm{~mL}$ per $\mathrm{kg}$ of this product in the diet. These results corroborate with Braccini et al. (2013), where a higher number of hepatocytes was verified in the liver of Nile tilapia fed Homeopatila $100^{\circledR}\left(40 \mathrm{~mL} \mathrm{~kg}^{-1}\right)$ compared to the control group.

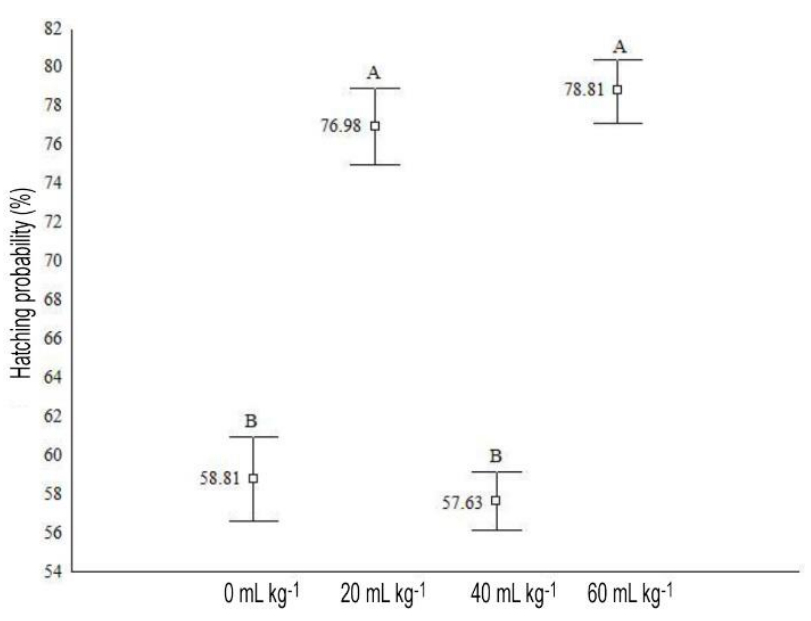

Figure 2. Hatching probability of zebrafish Danio rerio larvae fed different levels of Homeopatila $100^{\circledR}$. Different letters indicate statistically significant differences between treatments.

Although the animals evaluated have not been subjected to a stress condition, the highest number of hepatocytes verified with the inclusion of the homeopathic complex is important. These cells are the first target in adverse situations like the exposure of the fish to an environment with toxic substances, demonstrating that the homeopathic complex Homeopatila $100^{\circledR}$ acts in a beneficial way on the liver parameters, demonstrating that the action of this product results in a hepatoprotective effect.

The percentage of glycogen present in hepatocytes was lower in females fed without Homeopatila $100^{\circledR}$. The largest amount of this reserve substance in the treatment containing $40 \mathrm{~mL}$ of the homeopathic complex per $\mathrm{kg}$ of feed was also verified for Nile tilapia (Braccini et al., 2013). Nevertheless, the percentage of glycogen present inside zebrafish hepatocytes was higher than that observed in Nile tilapia.

When fish are well fed, hepatocytes store significant amounts of glycogen and process large amounts of lipids. In this research, fish were given a high-quality commercial diet, being thus, well nourished. Besides, Braccini et al. (2013) state that the studied homeopathic complex improves protein absorption and, therefore, provides a higher reserve of glycogen in the fish organism.

The number of eggs was higher for females fed diets containing 40 and $60 \mathrm{~mL}$ of Homeopatila $100^{\circledR}$, demonstrating the positive effect of the product on this reproductive parameter. The number of eggs is an important factor considered in the production of fish, since the quantity is related to the individuals generated and made available in the productive system. Also, the hatching probability is paramount. We observed higher 
hatching probability of zebrafish embryos from treatments with 20 and $60 \mathrm{~mL}$ of Homeopatila $100^{\circledR}$ per kg of feed.

The probability of greater hatching in the treatments containing the homeopathic complex may be related to the positive action on the reproductive metabolism of the females. The process of vitellogenesis, in which reserves are stored in oocytes originating the vitello, is essential for embryonic development after fertilization (Levi et al., 2009). Nutrition of breeders influences this stage and the liver plays a key role in reproductive metabolism. Precursors of vitellogenin are synthesized in the liver, secreted into the plasma and transported to the oocytes and later used in vitellogenesis (Levi et al., 2009). According to these authors, during this process, during sexual maturation, there are some metabolic alterations, such as depletion of plasma proteins, calcium, magnesium and glycogen.

In the present study, the females fed Homeopatila $100^{\circledR}$ had a higher percentage of glycogen in the hepatocytes. Among the evaluated levels, the values were lower for those consuming diet with 20 and $60 \mathrm{~mL}$ of the product per $\mathrm{kg}$ of diet. On the other hand, the reproduction of individuals of these treatments resulted in a higher probability of hatching of the larvae, and it can be considered that the observed glycogen depletion is related to its use in the vitellogenesis process, reflecting the better development of the embryos.

Homeopathy acts by supporting the body to restore balance after adverse situations, such as stress. Several situations related to the productive system cause stress and affect the balance of fish kept in captivity. They may be of exogenous origins such as management, stocking density and water quality, or endogenous, such as the metabolism involved in gonadal maturation and reproduction.

Stress causes physiological and biochemical imbalance, affecting the productive and reproductive parameters of the fish, including negative action on the liver and the decrease in the quality of gametes (Papadaki et al., 2008). Animals reared in conditions of low stress better develop their production potential (Siena et al., 2010). In this way, it is prudent to apply measures aimed at the return to homeostasis, which may be using homeopathic products, given the advantages of this therapeutic form.

\section{CONCLUSIONS}

The homeopathic complex Homeopatila $100^{\circledR}$ acts in a beneficial way in the zebrafish organism, increasing the number of hepatocytes and percentage of glycogen and favoring the reproduction, resulting in higher number of eggs per female and hatching probability of the embryos. It is recommended to use $60 \mathrm{~mL}$ of Homeopatila $100^{\circledR}$ per $\mathrm{kg}$ of feed in zebrafish feed.

\section{ACKNOWLEDGMENTS}

The authors are grateful to CAPES and RealH for financial support.

\section{REFERENCES}

Andretto, A.P., Fuzinatto, M.M., Bonafe, E.G., Braccini, G.L., Mori, R.H., Pereira, R.R., Oliveira, C.A.L., Visentainer, J.V. \& Vargas, L. 2014. Effect of a homeopathic complex on fatty acids in muscle and performance of the Nile tilapia (Oreochromis niloticus). Homeopathy, 103: 178-185.

Andretto, A.P., Lösh, J.A., Gonçalves, G.A., Fuzinatto, M.M., De Lima, D.P., Braccini, G.L., Alexandre Filho, L., Canan, C., Peralta, R.M. \& Vargas, L. 2015. Assessment of the oxidative state, related parameters and quality of muscle tissue in Nile tilapia with the application of homeopathic product Homeopatila 100 in high-density cages. African Journal of Pharmacy and Pharmacology, 9: 279-286.

Benez, S.M., Boericke, S., Cairo, N., Jacobs, P.H., MacLeod, G., Schroyens, F., Tiefenthaler, A., Vijnovsky, B. \& Wolff, H.G. 2004. Manual da homeopatia veterinária - indicações clínicas e patológicas: teoria e prática. Tecmedd, Ribeirão Preto.

Bonamin, L.V., Cardoso, T.N., Cunha de Carvalho, A. \& Amaral, J.G. 2015. The use of animal models in homeopathic research - a review of 2010-2014 PubMed indexed papers. Homeopathy, 104: 283-291.

Braccini, G.L., Natali, M.R.M., Ribeiro, R.P., Mori, R.H., Riggo, R., Oliveira, C.A.L., Hildebrandt, J.F. \& Vargas, L. 2013. Morpho-functional response of Nile tilapia (Oreochromis niloticus) to a homeopathic complex. Homeopathy, 102: 233-241.

Chang, J., Liu, S., Zhou, S., Wang, M. \& Zhu, G. 2013. Effects of butachlor on reproduction and hormone levels in adult zebrafish (Danio rerio). Experimental and Toxicologic Pathology, 65: 205-209.

Chatfield, K., Mathie, R.T., Bonamin, L.V., Oberbaum, M. \& Fisher, P. 2016. The publication in homeopathy of studies involving animal experimentation. Homeopathy, 105: 211-216.

Ernst, E. 2002. A systematic review of systematic reviews of homeopathy. British Journal of Clinical Pharmacology, 54: 577-582.

Fuzinatto, M.M., De Lima, D.P., Andretto, A.P., Menezes, L.A., Souza, A.H.P., Franco, M.L.D.S., Steinmacher, 
N.C., de Mendonça, S.N.T.G. \& Vargas, L. 2015. Influence of a homeopathic product on performance and quality flour and cookie (Grissini) of Nile Tilapia. African Journal of Pharmacy and Pharmacology, 9: 675-683.

Geweke, J. 1992. Evaluating the accuracy of samplingbased approaches to calculating posterior moments. In: Bernado, J., Berger, J., Dawid, A. \& Smith, A. (Eds). Bayesian statistics. Clarendon Press, Oxford, pp.169193.

Goessling, W. \& Sadler, K.C. 2015. Zebrafish: an important tool for liver disease research. Gastroenterology, 149: 1361-1377.

Gonzales, J.M. \& Law, S.H.W. 2013. Feed and feeding regime affect growth rate and gonadosomatic index of adult zebrafish (Danio Rerio). Zebrafish, 10: 532-540.

Grush, J., Noakes, D.L.G. \& Moccia, R.D. 2004. The efficacy of clove oil as an anesthetic for the zebrafish, Danio rerio (Hamilton). Zebrafish, 1: 46-53.

Heidelberger, P. \& Welch, P. 1983. Simulation run length control in the presence of an initial transient. Operations Research, 31: 1109-1144.

Howe, K., Clark, M.D., Torroja, C.F., Torrance, J., Berthelot, C., Muffato, M., Collins, J.E., et al. 2013. The zebrafish reference genome sequence and its relationship to the human genome. Nature, 496: 498503.

Júnior, R.P., Vargas, L., Valentim-Zabott, M., Ribeiro, R.P., Da Silva, A.V. \& Otutumi, L.K. 2012. Morphometry of white muscle fibers and performance of Nile tilapia (Oreochromis niloticus) fingerlings treated with methyltestosterone or a homeopathic complex. Homeopathy, 101: 154-158.

Levi, L., Pekarski, I., Gutman, E., Fortina, P., Hyslop, T., Biran, J., Levavi-Sivan, B. \& Lubzens, E. 2009. Revealing genes associated with vitellogenesis in the liver of the zebrafish (Danio rerio) by transcriptome profiling. BMC Genomics, 10: 141.

Lima, D.P., Fuzinatto, M.M., Andretto, A.P., Braccini, G.L., Mori, R.H., Canan, C., de Mendonça, S.N.T.G., de Oliveira, C.A.L., Ribeiro, R.P. \& Vargas, L. 2015. Mechanically separated fillet and meat nuggets of Nile tilapia treated with homeopathic product. African Journal of Pharmacy and Pharmacology, 9: 182-189.

Received: 11 December 2018; Accepted: 19 March 2019
Nasiadka, A. \& Clark, M.D. 2012. Zebrafish breeding in the laboratory environment. ILAR Journal, 53: 161168.

Papadaki, M., Papadopoulos, M., Siggelaki, I. \& Mylonas, C.C. 2008. Egg and sperm production and quality of sharp snout sea bream (Diplodus puntazzo) in captivity. Aquaculture, 276: 187-197.

Pinheiro, D.A., Cavero, B.A.S., Vargas, L., Braccini, G.L., Yoshioka, E.T.O., Oliveira, M.S.B. \& TavaresDias, M. 2015. Performance, parasitic infections, hematology and hepatic histology of Colossoma macropomum (tambaqui) fed on homeopatic product. African Journal of Pharmacy and Pharmacology, 9: 82-90.

R Core Team. 2018. R: a language and environment for statistical computing. R Foundation for Statistical Computing. [http://www.R-project.org]. Reviewed: 27 November 2018.

Siena, C.E., Natali, M.R.M., Braccini, G.L., De Oliveira, A.C., Ribeiro, R.P. \& Vargas, L. 2010. Efeito do núcleo homeopático Homeopatila $100 \circledast$ na eficiência produtiva em alevinos revertidos de tilápia do nilo (Oreochromis niloticus). Semina: Ciências Agrárias, 31: 985.

Spence, R., Ashton, R. \& Smith, C. 2007. Oviposition decisions are mediated by spawning site quality in wild and domesticated zebrafish, Danio rerio. Behaviour, 144: 953-966.

Spiegelhalter, D.J., Best, N.G., Carlin, B.P. \& Van der Linde, A. 2002. Bayesian measures of model complexity and fit. Journal of the Royal Statistical Society, Series B, 64: 583-639.

Valentim-Zabott, M., Vargas, L., Ribeiro, R.P., Piau, R., Torres, M.B.A., Rönnau, M. \& Souza, J.C. 2008. Effects of a homeopathic complex in Nile tilapia (Oreochromis niloticus L.) on performance, sexual proportion, and histology. Homeopathy, 97: 190-195.

Vilella, A.J., Severin, J., Ureta-Vidal, A., Heng, L., Durbin, R. \& Birney, E. 2008. EnsemblCompara GeneTrees: complete, duplication-aware phylogenetic trees in vertebrates. Genome Research, 19: 327-335. 